\title{
Nutrients Flow as Affected by Cropping System and Production Niche in Smallholder Farmers of Cyabayaga Watershed
}

\author{
Michel Kabirigi1* ${ }^{*}$ Bernard Musana1, Desire Mbarushimana Kagabo², \\ Athanase Mukuralinda ${ }^{3}$, Nsharwatsi Leon Nabahungu ${ }^{4}$ \\ ${ }^{1}$ Rwanda Agriculture Board (RAB), Research Unit of Natural Resources Management, Kigali, Rwanda \\ ${ }^{2}$ International Center for Tropical Agriculture (CIAT), Kigali, Rwanda \\ ${ }^{3}$ International Council for Research in Agroforestry (ICRAF), Kigali, Rwanda \\ ${ }^{4}$ International Institute of Tropical Agriculture (IITA), Bukavu, Democratic Republic of the Congo \\ Email: "kabirimi@yahoo.fr
}

Received 2 February 2016; accepted 9 May 2016; published 12 May 2016

Copyright (C) 2016 by authors and Scientific Research Publishing Inc.

This work is licensed under the Creative Commons Attribution International License (CC BY). http://creativecommons.org/licenses/by/4.0/

c) (i) Open Access

\section{Abstract}

Nutrient-balance assessments are valuable tools for both planning and monitoring the implementation of sustainable integrated soil fertility management strategies. The aim of this study was to assess nutrient flows as affected by cropping systems and production niche in soils of Cyabayaga watershed. yabayaga watershed is located in Nyagatare district, Eastern province of Rwanda. Production niches considered are homestead fields, remote hillside fields and wetland fields. Partial nutrient (N, P and $\mathrm{K}$ ) flows were collected through a survey using MonQi structured questionnaire, administrated to a random sample of 35 farmers. There was nitrogen $(\mathrm{N})$ and Potassium (K) negative balances (-67.5 $\mathrm{kg} \mathrm{N} \mathrm{ha}^{-1}$ season $^{-1}$ and $-7.7 \mathrm{~kg} \mathrm{~K}^{-1}$ season $^{-1}$ respectively) whereas

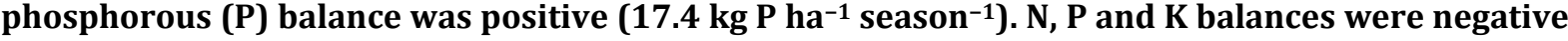
in bean, maize-bean, cassava, groundnut, maize, onion, sorghum and tomato and positive in rice, banana and banana-bean. Highest amount of nutrients were significantly allocated in wetland fields while allocation of nutrients in homestead fields and remote hillside fields was almost the same. Groundnut and maize plots were experiencing highest negative nutrients balance (e.g. $\mathrm{N}$

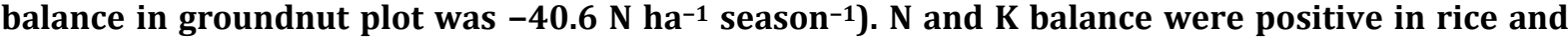
banana plots; whilst $P$ balance was positive in banana, bean, maize, rice and tomato plots. Partial nutrients flow and balance from this study show that nutrient depletion is a problem in the study area. A special attention should be put to fertility management and alternative solution for less fertile soil (uplands in particular), especially for farm that have reduced land size. From this respect,

\footnotetext{
${ }^{*}$ Corresponding author.
}

How to cite this paper: Kabirigi, M., Musana, B., Kagabo, D.M., Mukuralinda, A. and Nabahungu, N.L. (2016) Nutrients Flow as Affected by Cropping System and Production Niche in Smallholder Farmers of Cyabayaga Watershed. Agricultural Sciences, 7, 287-294. http://dx.doi.org/10.4236/as.2016.75028 
conservation agriculture is the main farm management which could be recommended.

\author{
Keywords
}

Nutrient Balance, Production Niches, ISFM, Cyabayaga Watershed

\title{
1. Introduction
}

In Rwanda, besides agriculture's contribution to GDP, the sector typically generates about $90 \%$ of employment (especially for women), about $70 \%$ of export revenues and about $90 \%$ of national food need [1]. Attempts to increase agricultural production and food consumption are destabilized by rapid population growth [2]. Consequently, crop productivity is declining [1] [3] as a result of intensive farming, which leads to soil loss through erosion and declining soil fertility [4]. Furthermore nutrient mining is extensive on many smallholder farms of Rwanda and is worsened by continuous cropping, inadequate nutrient replenishment in relation to plant demand, and high rates of soil erosion, leaching and removal of crop residues from the fields [5] [6]. As a result, soil fertility has continued to decline to levels that are currently prohibitive to profitable agriculture [4].

Advancing food security and environmental sustainability in farming systems require an implementation of integrated soil fertility management that minimize the mining of soil nutrient reserve and degradation of soil physical and biological properties [7] [8]. Sustainability of agricultural systems is regarded as key to the development of sustainable agriculture-management systems which is a major global concern due a number of environmental factors [9]. Thus Integrated Soil Fertility Management (ISFM) is widespread as a strategy that can address the complexities and peculiarities of soil fertility management on smallholder farms, help low resource endowed farmers mitigate problems of poverty and food insecurity by improving the quantity of food, income and resilience of soil productive capacity [10]. Nutrients flow analysis is a key to plan, implement and monitor ISFM technologies for sustainable soil fertility management.

Studies have revealed that Rwanda has one of the most severe declining nutrient rates in Africa, with on average $-54 \mathrm{~kg} \mathrm{~N},-9 \mathrm{~kg} \mathrm{P}$ and $-47 \mathrm{~kg} \mathrm{~K} \mathrm{ha}^{-1}$ year $^{-1}$ [11] [12]. Without investment in land improvement, soil erosion and soil fertility decline will continue, leading to low agricultural productivity and hence increased food insecurity and reduced cash income. Nutrient-balance assessments are valuable tools for delineating the consequences of farming on soil fertility as well as to assess the sustainability of agro-ecosystems and provide information to answer the question whether changes in productivity are to be expected [13]. Furthermore such analyses help in the design of effective policy which supports improved soil fertility management by small-holder farmers [6]. In addition, in case of imbalances, the major in- or outgoing fluxes can be identified and nutrient management and/or land-use strategies may be adapted accordingly. In other words it is important to calculate and monitor nutrient flows to quantify the impact of integrated nutrients management systems on soil fertility and sustainable agricultural productivity [14]. However there are a limited number of long-term studies monitoring the nutrient status of soils, nutrient balances, and crop productivity in Rwanda [12]. This study assessed partial nutrients flows in soils of Cyabayaga watershed. Partial nutrient inflows, outflows and balances, nutrients destination and allocation at farm level in Cyabayaga watershed were determined.

\section{Materials and Methods}

\subsection{Study Area}

The study on nutrient flows within the farm was conducted in small scale farms around Cyabayaga watershed (Figure 1). Cyabayaga watershed is located in Nyagatare district, Eastern province of Rwanda. It lies at latitude $1^{\circ} 22^{\prime} 51.6^{\prime \prime}$ South of the Equator and longitude $30^{\circ} 17^{\prime} 07^{\prime \prime}$ East. The area lies in the low lying eastern savannah agro-ecological zone at an average altitude of $1400 \mathrm{~m}$ above sea level. Rainfall ranges from $800-1000 \mathrm{~mm}$ per annum and often erratic. The soils in this area are relatively fertile as this area is rather recently opened for cultivation. According to the FAO soil taxonomy, soils of Cyabayaga watershed are dominated by Humic Ferrasols (Deep, strongly weathered soils with a chemically poor, but physically stable soil) in upland and Vertisols (With dark colored cracking and swelling clay) in wetland. Mixed farming system in the hillsides with large diversity of crops e.g. beans, maize, banana, sweet potatoes, sorghum, cassava characterize the cropping systems of the 


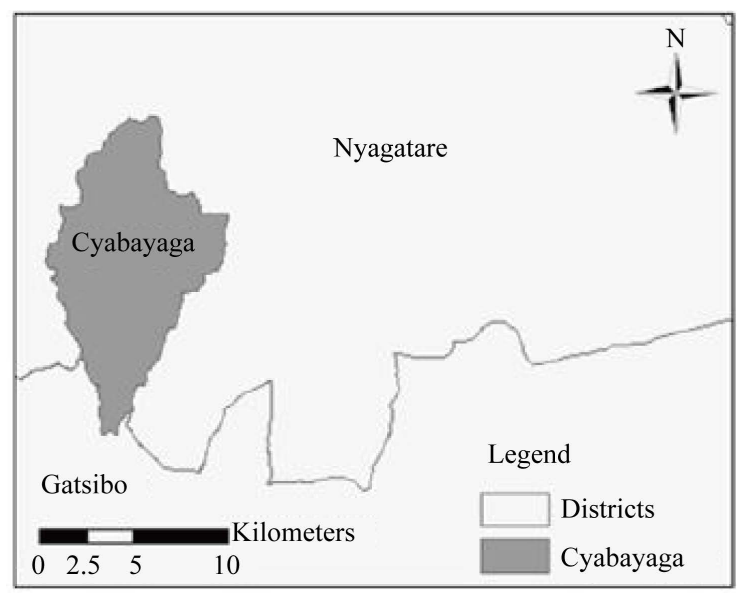

Figure 1. Map showing the boundary of the watershed. Source: [12].

study areas. In wetlands, rice mono-cropping is practiced. Rain-fed agriculture is practiced in the hillside whereas in the wetland farmers relay both on irrigation and rain-fed agriculture. Extensive system of livestock keeping is more important in Cyabayaga.

\subsection{Methodology}

Data was collected through a survey using structured questionnaire addressed to the sample of 35 randomly selected farmers. Detailed information on nutrient (N, P and K) flows between and within farms was collected using the NUTMON toolbox (now known as MonQI). NUTMON/MonQI is a methodology for monitoring management and performance of small scale farming systems world-wide. Briefly, farmers were extensively interviewed about their farm management practices using standardized questionnaires. The study estimated partial nutrient balance thus it was limited on organic and inorganic fertilization as inflow. After collecting all data, they were entered using data entry part of MonQI toolbox and after all processed to get nutrient flows. Data were exported in Microsoft Excel which facilitates the use of pivot tables. Frequency tables were generated using Statistical package for Social Scientists (SPSS) 16 for Windows.

\subsection{MonQI Toolbox Description}

MonQI is a multi-scale and multi-disciplinary approach for monitoring management and performance of small scale agricultural enterprises world-wide with the aim of improving the quality of farm management, crop production, quality of produce, livelihoods and environment. The rational behind MonQI is that integrated monitoring of agricultural enterprises helps to understand these enterprises and paves the way for improvements in social, economic, agricultural and environmental conditions. MonQI is a research framework for systematic (financial) analysis of agricultural systems at farm level and describes the existing management situation. The methodology is flexible and can be modified according to the research needs. MonQI Toolbox is a set of materials (questionnaire, software and manuals) for the application of the methodology. MonQI monitoring and analysis focuses on the household/farm/enterprise and the sub-activities that these include. Its results can be aggregated from the lowest (activity) level to the higher levels such as household, village and (sub) district.

The MonQI toolbox consists of several components, three of which have been integrated into one software program:

- Data-Entry Module (DEM)

- Background Data Module (BDM)

- Background Processing Module (BDM)

These three module make use of two databases

- Background database (BGDB), containing shared background data

- Farm database (FDB), containing the farm inventory and management data.

Information is gathered using a paper questionnaire. 


\section{Results}

\subsection{Characteristics of Respondents}

Majority of the head of households were males constituting $93.9 \%$ while $6.1 \%$ of the household were female headed. The age of household heads ranged from 23 years to 69 years with an average age of 44 years \pm 12 . Farmers who have attended school were $63.6 \%$ while $36.4 \%$ have not been to school. Education years ranged from 0 year to 9 years with an average of 4 years \pm 3 . Most of farmers keep goats, indigenous cattle and chicken. Crossed breed cattle, ducks, pigs and sheep were also kept by few farmers.

\subsection{Nutrients Input, Output and Balance in the Watershed}

Results presented in Figure 2 highlight that there was an alarming nitrogen $(\mathrm{N})$ negative balance $(-67.5 \mathrm{~kg} \mathrm{~N}$ $\mathrm{ha}^{-1}$ season $^{-1}$ ) indicating that the output (Nitrogen pool through harvest and residues) was higher than the input. There was also Potassium $(\mathrm{K})$ negative balance $\left(-7.7 \mathrm{~kg} \mathrm{~K} \mathrm{ha}^{-1}\right.$ season $\left.^{-1}\right)$ indicating that the input was less than the output. However phosphorous (P) balance was positive $\left(17.4 \mathrm{~kg} \mathrm{P} \mathrm{ha}^{-1}\right.$ season $\left.^{-1}\right)$ suggesting that the $\mathrm{P}$ input was higher than the output.

\subsection{Nutrients Balances in Cropping Systems}

In general $\mathrm{N}, \mathrm{P}$ and $\mathrm{K}$ balances were negative in bean, maize-bean, cassava, groundnut, maize, onion, sorghum and tomato and positive in rice, banana and banana-bean (Table 1). In addition there was a positive P balance in tomato while for $\mathrm{N}$ and $\mathrm{K}$ the balance was negative.

\subsection{Nutrients Allocation}

There was a significant difference $(\mathrm{P}=0.016)$ in $\mathrm{P}$ allocation in different production niches (Table 2). Higher $\mathrm{P}$
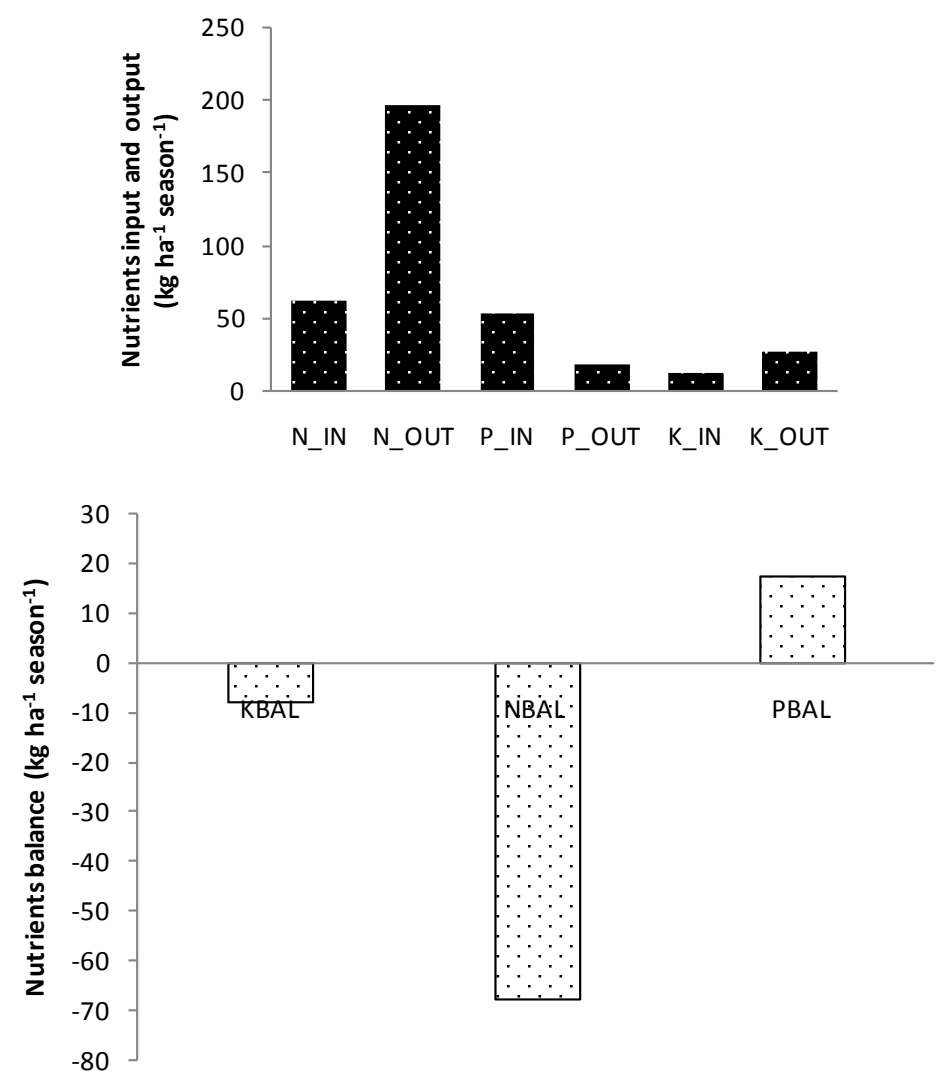

Figure 2. Nutrients input, output and balance in the watershed. 
Table 1. Average N, P, K balances in cropping systems.

\begin{tabular}{|c|c|c|c|}
\hline Cop/cropping system & N ( $\mathrm{kg} \mathrm{ha}^{-1}$ season $\left.^{-1}\right)$ & P $\left(\mathrm{kg} \mathrm{ha}^{-1}\right.$ season $\left.^{-1}\right)$ & $\mathrm{K}\left(\mathrm{kg} \mathrm{ha}^{-1} \operatorname{season}^{-1}\right)$ \\
\hline Banana & 4.45 & 1.37 & 3.03 \\
\hline Banana | Bean & 9.10 & 5.70 & 30.07 \\
\hline Bean & -14.19 & 27.43 & -26.18 \\
\hline Bean | Maize & -28.89 & -3.22 & -21.33 \\
\hline Cassava & -10.47 & -1.25 & -10.47 \\
\hline Groundnut & -40.05 & -6.38 & -9.47 \\
\hline Homestead & 1.15 & 0.39 & 1.80 \\
\hline Maize & -40.28 & 47.99 & -27.28 \\
\hline onion & -4.35 & -0.74 & -4.86 \\
\hline Rice & 43.30 & 6.12 & 14.65 \\
\hline Sorghum & -17.67 & -2.80 & -1.42 \\
\hline Sweet potato & -3.71 & -0.86 & -5.64 \\
\hline Tomato & -38.03 & 1.81 & -24.75 \\
\hline
\end{tabular}

Table 2. Nutrients allocation at farm level in the watershed $\left(\mathrm{kg} \mathrm{ha}^{-1} \operatorname{season}^{-1}\right)$.

\begin{tabular}{cccc}
\hline Niche & $\mathbf{N}$ & $\mathbf{P}$ & $\mathbf{K}$ \\
\hline Homestead field & 30.8 & 2.3 & 0.7 \\
Remote hillside field & 11 & 0.6 & 0.9 \\
Wetland & 28 & 9.7 & 18.6 \\
F pr. & 0.679 & 0.016 & $<.001$ \\
s.e.d. & 24.12 & 2.96 & 2.6 \\
\hline
\end{tabular}

was allocated in wetland $\left(9.7 \mathrm{~kg} \mathrm{ha}^{-1}\right.$ season $\left.^{-1}\right)$ while lower $\mathrm{P}$ was allocated in remote hillside fields $\left(0.6 \mathrm{~kg}^{-1}\right.$ season $\left.^{-1}\right)$. Potassium allocation was very highly significantly different $(\mathrm{P}<0.001)$ between production niches. Higher $\mathrm{K}$ was allocated in wetland $\left(18.6 \mathrm{~kg} \mathrm{ha}^{-1}\right.$ season $^{-1}$ ) while lower $\mathrm{K}$ was allocated in remote hillside fields $\left(0.9 \mathrm{~kg} \mathrm{ha}^{-1}\right.$ season $\left.^{-1}\right)$. Nitrogen allocation was not significantly different $(\mathrm{P}=0.679)$.

\subsection{Nutrients Destination}

Table 3 shows that market was the major sink of nitrogen from crops, but also the market was the major source of nitrogen (148 kg of N). Crops, redistribution and store also constituted to the source of nitrogen with $4.55 \mathrm{~kg}$ of $\mathrm{N}, 20.43 \mathrm{~kg}$ of $\mathrm{N}$ and $8.22 \mathrm{~kg}$ of $\mathrm{N}$ respectively. It was realized that livestock, crop, other, redistribution and store were also the sink of nitrogen with $0.01 \mathrm{~kg}$ of $\mathrm{N}, 0.35 \mathrm{~kg}$ of N, $0.23 \mathrm{~kg}$ of N, $0.05 \mathrm{~kg}$ of $\mathrm{N}$ and $6.17 \mathrm{~kg}$ of $\mathrm{N}$ respectively. Market was again the major source of phosphorous with $76.88 \mathrm{~kg}$ of $\mathrm{P}$ to crops, $0.18 \mathrm{~kg}$ of $\mathrm{P}$ to livestock and $0.28 \mathrm{~kg}$ of $\mathrm{P}$ to store. Crop, redistribution and store were also source of phosphorous to crops with $0.85 \mathrm{~kg}$ of $\mathrm{P}, 2.59 \mathrm{~kg}$ of $\mathrm{P}$ and $1.18 \mathrm{~kg}$ of $\mathrm{P}$ to crops respectively. Sinks of phosphorous from crops were livestock (0.20 kg of P), market (12.94 kg of P), crop (0.85 kg of P), other (0.20 kg of P), redistribution ( $0.58 \mathrm{~kg}$ of $\mathrm{P})$ and store (4.3 kg of P). The major source of potassium was market with $0.28 \mathrm{~kg}$ of $\mathrm{K}$ to livestock, $33.65 \mathrm{~kg}$ of $\mathrm{K}$ to crops and $2.34 \mathrm{~kg}$ of $\mathrm{K}$ to store. Other sources of potassium were livestock, crops, redistribution and store. Sinks of potassium from crops were livestock (1.16 kg of K), market (19.16 kg of K), crop (6.62 kg of K), other (1.60 kg of K), redistribution (7.06 kg of K) and store (11.56 kg of K). 
Table 3. Nutrients destination (kg).

\begin{tabular}{|c|c|c|c|c|c|c|c|}
\hline & & To & & & & & \\
\hline & From & Livestock & Market & Crop & Other & Redistribution & Store \\
\hline \multirow[t]{5}{*}{ Nitrogen } & Livestock & & 0 & & & & 382.17 \\
\hline & Market & 3.7 & & 148 & & & 2.75 \\
\hline & Crop & 0.4 & 60.75 & 4.55 & 1.13 & 3.99 & 26.75 \\
\hline & Redistribution & & & 20.43 & & & \\
\hline & Store & & & 8.22 & & & \\
\hline \multirow[t]{5}{*}{ Phosphorous } & Livestock & & 0 & & & & 2.63 \\
\hline & Market & 0.18 & & 76.88 & & & 0.28 \\
\hline & Crop & 0.2 & 12.94 & 0.85 & 0.2 & 0.58 & 4.3 \\
\hline & Redistribution & & & 2.59 & & & \\
\hline & Store & & & 1.18 & & & \\
\hline \multirow[t]{5}{*}{ Potassium } & Livestock & & 0 & & & & 4.78 \\
\hline & Market & 0.28 & & 33.65 & & & 2.34 \\
\hline & Crop & 1.16 & 19.16 & 6.62 & 1.6 & 7.06 & 11.56 \\
\hline & Redistribution & & & 23.27 & & & \\
\hline & Store & & & 3.78 & & & \\
\hline
\end{tabular}

\section{Discussion}

Rwanda, having limited land area, must increase yields per unit land area to improve its food security. Partial nutrients flow and balance from this study show that nutrient depletion is a major problem in the study area. There was $\mathrm{N}$ and $\mathrm{K}$ negative balances which is in agreement with most of studies carried out in Africa indicating that balances are usually negative, suggesting potential problems of soil mining, especially for $\mathrm{N}$ and $\mathrm{K}$; while for $\mathrm{P}$ the trend is less remarkable [15]. As it has been discussed by [16] if soil nutrients are not replenished, the supply from the available stock will decrease with time as a result nutrients imbalance will contributes to a growing yield gap. Furthermore negative nutrients balances have the potential to further limit food production for a growing population in Rwanda.

There was a significant difference in $\mathrm{K}$ and $\mathrm{P}$ balance between production niches (Homestead fields, Remote hillside fields and wetland fields). Allocation of higher nutrients in wetland is justified by rice crop which is cultivated in wetland since it is considered as a cash crop in the area. It has been discussed that farmers face multiple trade-offs when deciding on the allocation of their financial, labor and nutrient Resources [17]. According to [18], livestock, gross margin ha $^{-1}$, wealth classes, agricultural niches and sites are important determinants of partial nutrient flows and balances in Rwanda; however, farm size do not show a negative influence. Furthermore agricultural potential, farming system (choice of crops), access to resources, gross margin, size of livestock herd and farmers resource endowment influence the magnitude and the degree to which nutrients fluxes may be imbalanced [12].

There was N, P and K flows between farm compartments (Crop, Livestock, Market, Redistribution and Homestead) suggesting the possibility of reuse of nutrients within farming systems. Finding agreed with van Beek [19] who observed major N fluxes between household and crops. However, findings of this study disagree with Tittonel [20] who analyzed trade-offs between different farmers' objectives and compared potential resource allocation strategies to achieve them and highlighted that the allocation of $\mathrm{N}$ fertilizer favored the more fertile fields located closer to the homestead, where the efficiency of N capture was greater. Tittonel [20] is in agreement with Foli [21] who indicated that the location of fields, especially the distance to the farm, strongly influences nutrient inputs. Van Beek et al. [19] highlighted that the reuse of nutrients within the farm, which occur 
when nutrients pass through several farm compartments before they leave the farm via marketable products, would lead to sustainable food production in nutrient limited production systems.

In Rwanda recent efforts have been concentrated on Crop Intensification Program (CIP), aiming at boosting agricultural productivity through an improvement of productive inputs use, irrigation and rainwater use efficiency and soil quality, nevertheless, yields remain far below potential [1]. This study suggests the adoption of farming system strategies that promote the reuse of nutrients within farming systems such as conservation agriculture [22]. Farms in Rwanda, like in most of smallholder farms in sub-Saharan Africa, are highly diverse and heterogeneous, often operating in complex socio-ecological environments [23]. This hinders the evaluation of relations between various farm performance indicators and of consequences of adjustments in farm management [24]. From this respect the study highlights the importance of further analysis which links hillsides and wetlands in analyzing farm household systems in Rwanda as well as reconfiguration of farming systems to reach various productive and environmental objectives. This study support Wasige [25] that low levels of nutrients in agricultural soil raises the problem of sustainable food production in Rwanda.

\section{Conclusion and Recommendations}

Partial nutrients flow and balance from this study show that nutrient depletion is a major problem in the study area. Highest amount of nutrients were significantly allocated in wetland fields which highlights the affirmation that the value and marketability of the crops produced are therefore critical factors in the decision to invest in soil fertility improvement. Thus farmers may not necessarily be concentrating nutrients around their homestead because of the short distance. Rather, farmers apply nutrients in plots which they perceive to be fertile and secure to produce satisfactory yields. N, P and K balances were negative in bean, maize-bean, cassava, groundnut, maize, onion, sorghum and tomato and positive in rice, banana and banana-bean cropping systems. The results brought the following recommendations forward: Famers in study area should adopt Integrated Nutrients Management strategies which perceived as the judicious manipulation of nutrient inputs (mineral fertilizers, organic inputs, deposition, nitrogen fixation, sedimentation and subsoil exploitation of nutrients by deep-rooted crops or trees), outputs (harvested or marketable farm products, residues/manures, leaching, gaseous losses, erosion and human wastes) and internal flows. Finding of this study provides a starting point of sustainable integrated soil fertility management strategies policies development. A special attention should be put to fertility management and alternative solution for less fertile soil (uplands in particular), especially for farms that have reduced land size.

\section{References}

[1] Cantore, N. (2011) The Crop Intensification Program in Rwanda: A Sustainability Analysis. Overseas Development Institute.

http://dspace.cigilibrary.org/jspui/bitstream/123456789/31634/1/ODI-\%20The\%20Crop\%20Intensification\%20Progra $\underline{\mathrm{m} \% 20 \mathrm{in} \% 20 \mathrm{Rwanda} . \mathrm{pdf}}$

[2] Boserup, E. (2005) The Conditions of Agricultural Growth: The Economics of Agrarian Change under Population Pressure. Transaction Publishers, Piscataway.

[3] Kelly, V., et al. (2001) Agricultural Intensification in Rwanda: An Elusive Goal. Food Security Research Project/ Division of Agricultural Statistics Policy Brief. Ministry of Agriculture, Animal Resources and Forestry, Kigali.

[4] Kagabo, D.M., Stroosnijder, L., Visser, S.M. and Moore, D. (2013) Soil Erosion, Soil Fertility and Crop Yield on Slow-Forming Terraces in the Highlands of Buberuka, Rwanda. Soil and Tillage Research, 128, 23-29. http://dx.doi.org/10.1016/j.still.2012.11.002

[5] Vanlauwe, B. and Zingore, S. (2011) Integrated Soil Fertility Management: An Operational Definition and Consequences for Implementation and Dissemination. Better Crops with Plant Food, A Publication of the International Plant Nutrition, p. 4.

[6] Drechsel, P., Gyiele, L., Kunze, D. and Cofie, O. (2001) Population Density, Soil Nutrient Depletion, and Economic Growth in Sub-Saharan Africa. Ecological Economics, 38, 251-258. http://dx.doi.org/10.1016/S0921-8009(01)00167-7

[7] Vanlauwe, B., Bationo, A., Chianu, J., Giller, K.E., Merckx, R., Mokwunye, U., et al. (2010) Integrated Soil Fertility Management Operational Definition and Consequences for Implementation and Dissemination. Outlook on Agriculture, 39, 17-24. http://dx.doi.org/10.5367/000000010791169998

[8] Bucagu, C., Vanlauwe, B., Van Wijk, M.T. and Giller, K.E. (2014) Resource Use and Food Self-Sufficiency at Farm Scale within Two Agro-Ecological Zones of Rwanda. Food Security, 6, 609-628. http://dx.doi.org/10.1007/s12571-014-0382-0 
[9] Kimetu, J.M., Lehmann, J., Ngoze, S.O., et al. (2008) Reversibility of Soil Productivity Decline with Organic Matter of Differing Quality along a Degradation Gradient. Ecosystems, 11, 726-739. http://dx.doi.org/10.1007/s10021-008-9154-z

[10] Sanginga, N.S. and Woomer, P.L. (2009) Integrated Soil Fertility Management in Africa: Principles, Practices, and Developmental Process. Free download form CIAT.

[11] Wasige, J.E., et al. (2014) Soil Fertility and Nutrient Balances of Low Input Land Use Systems of South-West Rwanda, Upstream of Lake Victoria Basin. J Agric Ecosyst Environ (under review).

[12] Nabahungu, N.L. (2012) Problems and Opportunities of Wetland Management in Rwanda. Wageningen Universiteit (Wageningen University), Wageningen.

[13] Kagabo, M.D. (2013) Participatory Integrated Watershed Management in the North-Western Highlands of Rwanda. Wageningen University, Wageningen.

[14] Zingore, S., Murwira, H.K., Delve, R.J. and Giller, K.E. (2007) Influence of Nutrient Management Strategies on Variability of Soil Fertility, Crop Yields and Nutrient Balances on Smallholder Farms in Zimbabwe. Agriculture, Ecosystems \& Environment, 119, 112-126. http://dx.doi.org/10.1016/j.agee.2006.06.019

[15] Cobo, J.G., Dercon, G. and Cadisch, G. (2010) Nutrient Balances in African Land Use Systems across Different Spatial Scales: A Review of Approaches, Challenges and Progress. Agriculture, Ecosystems \& Environment, 136, 1-15. http://dx.doi.org/10.1016/j.agee.2009.11.006

[16] Nkonya, E. (2004) Strategies for Sustainable Land Management and Poverty Reduction in Uganda. International Food Policy Research Institute (IFPRI) Research Report \#133. Washington DC, Vol. 133.

[17] Tittonell, P., Dercon, G. and Cadisch, G. (2007) Analysing Trade-Offs in Resource and Labour Allocation by Smallholder Farmers Using Inverse Modelling Techniques: A Case-Study from Kakamega District, Western Kenya. Agricultural Systems, 95, 76-95. http://dx.doi.org/10.1016/j.agsy.2007.04.002

[18] Nabahungu, N.L. and Visser, S.M. (2013) Farmers’ Knowledge and Perception of Agricultural Wetland Management in Rwanda. Land Degradation \& Development, 24, 363-374. http://dx.doi.org/10.1002/ldr.1133

[19] van Beek, C.L., et al. (2009) Farm Nitrogen Flows of Four Farmer Field Schools in Kenya. Nutrient Cycling in Agroecosystems, 83, 63-72. http://dx.doi.org/10.1007/s10705-008-9199-6

[20] Tittonell, P. (2008) Msimu wa Kupanda: Targeting Resources within Diverse, Heterogeneous and Dynamic Farming Systems of East Africa. Wageningen Universiteit, Wageningen.

[21] Foli, S. (2012) Farm Characterisations in the Southern and Northern Guinea Savannah Zones of Nigeria. M.Sc. Thesis, Plant Production Systems, Wageningen University, Wageningen.

[22] Turmel, M.-S., et al. (2015) Crop Residue Management and Soil Health: A Systems Analysis. Agricultural Systems, 134, 6-16.

[23] Tittonell, P., Vanlauwe, B., Misiko, M. and Giller, K.E. (2011) Targeting Resources within Diverse, Heterogeneous and Dynamic Farming Systems: Towards a "Uniquely African Green Revolution". In: Innovations as Key to the Green Revolution in Africa, Springer, Location, 747-758. http://dx.doi.org/10.1007/978-90-481-2543-2_76

[24] Groot, J.C., Oomen, G.J. and Rossing, W.A. (2012) Multi-Objective Optimization and Design of Farming Systems. Agricultural Systems, 110, 63-77. http://dx.doi.org/10.1016/j.agsy.2012.03.012

[25] Wasige, E.J. (2013) A Spatially Explicit Approach to Determine Hydrology, Erosion and Nutrients Dynamics in an Upstream Catchment of Lake Victoria Basin. University of Twente Faculty of Geo-Information and Earth Observation (ITC), Enschede, ITC Dissertation 239. 